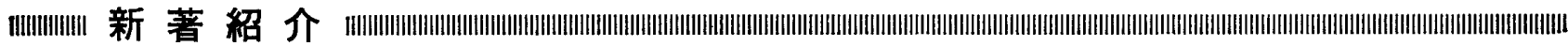

SADI 組織委員会編：ダニと疾患

$$
\text { のインターフェイス }
$$

\section{ACARI-DISEASES INTERFACE}

YUKI 書房（福井市)，1994 年 4 月，

$$
180 \text { pp., } 3,800 \text { 円 }
$$

（郵便振替 : YUKI 書房 00780-0-16290)

日本国内におけるダ二類媒介性疾患に関する知見は近 年急速に搪大し, これに伴って衛生動物学会の演題・学 会誌の掲載論文にも恙虫病, ライム病, 日本紅斑熱など に関する報告の増加傾向がみられる.

本書は 1993 年 9 月に開催された「ダニと疾患のイン ターフェイス」の第 1 回セミナーに抬ける報告内容を中 心に，紙上参加の論文を併せて編集されたもので，原 著, 総説，資料等 31 編からなる up-to-date な論文集と なっている. 本書の編集意図は, ダ二類媒介性疾患の媒 介種, 疫学, 臨床, 病原体など各分野の最近の研究動向 と新知見を総合的・学際的な観点から取り扱おうとする 試みであり，時宜を得た好著として高く評価することが できよう．原著・総説にはキーワードと Abstract が付 けられ，図・表はすべて英文で記載されている. 引用文
献もかなり豊富でよい参考になる。

本書の構成は，第 1 章 医ダ二学の基礎一特にヒトと の接点を中心に一，第 2 章 症例の検討一ダ二起因性疾 患の特性をみる一, 第 3 章 感染疫学一実地調查をもと に感染のしくみを探る一，第 4 章 病原体の検討一ダニ 由来病原体の問題点を示す一の四章およびキーワード索 引から成り，第 1 章ではダ二類の生理，生態，分布，季 節消長，ヒ卜刺症の機序なぞの基礎的事項が述べられ， 第 2 章以降には恙虫病, 日本紅斑熱, $Q$ 熱, エールリヒ ア症, 野兔病, ライム病, バベシア症などの感染症につ いて, 臨床, 感染疫学, 病原体などをめぐる最近の知見 が記載され，読みごたえのある論文が多い。

本書は, ダ二類媒介性疾患の研究状況を展望するにあ たって衛生動物学・臨床医学・病原微生物学なぞ関連分 野間の接点（インターフェイス）に着目し, 総合的研究 のあり方にひとつの指針を示した点で有意義であり，ま た日本国内のこれら疾患について現状認識を深めるため の資料としても価値が高い．本誌の紙面を借りて紹介し たしだいである.

（熊田信夫） 